\title{
Characteristics of Diode Rectifier Circuits for Three-Phase Rectangular-Waveform Distribution System
}

\author{
Shin-ichiro Watanabe Student Member (Nagoya Institute of Technology, watanbe@motion.elcom.nitech.ac.jp) \\ Takaharu Takeshita Senior Member (Nagoya Institute of Technology, take@nitech.ac.jp) \\ Yasuyuki Nishida Member (Nihon University, nishida@ee.ce.nihon-u.ac.jp)
}

Keywords: three-phase rectangular-waveform distribution system, diode rectifier circuit, commutation capacitor

This paper presents the theoretical and experimental characteristics of diode rectifier circuits for the three-phase rectangularwaveform distribution system.

Fig. 1 shows the comparison of the line voltage and current waveforms between the conventional sinusoidal- and proposed rectangular-waveform distribution systems under the unity total power factor and the same dc output voltage of the diode rectifier circuit. Both the amplitude and the rms value of the line current in the rectangular-waveform distribution system can be reduced to $\sqrt{3} / 2$ of those in the sinusoidal-waveform distribution system.

Fig. 2 shows the model of the proposed three-phase rectangularwaveform distribution system. The rectangular waveform voltage generator that consists of the PWM converter and the inverter, converts the utility three-phase sinusoidal-waveform voltage with the amplitude of $200 \mathrm{~V}$ and the frequency of $60 \mathrm{~Hz}$ into the three-phase rectangular-waveform voltage of $300 \mathrm{~V}$ and $400 \mathrm{~Hz}$. The load is a three-phase diode rectifier circuit of $3 \mathrm{~kW}$. The input inductance $L=0.5 \mathrm{mH}$ and the output smoothing capacitor $C_{d}=100 \mu \mathrm{F}$ in the diode rectifier circuit are selected according to the derived design methods under the specifications of the input total power factor $T P F=0.88$, the rated output voltage $V_{d}=290 \mathrm{~V}$ and the rated peak-to-peak fluctuation value of the output voltage $\Delta v_{d \max }=2.5 \mathrm{~V}$.

Fig. 3 shows the experimental waveforms of the line voltage $v_{u v}$, the input current $i_{u}$, the output current $i_{L}$ and the output dc voltage $v_{d}$ in the diode rectifier circuit under the rated load. The input total power factor $T P F=0.92$, the output voltage $V_{d}=289 \mathrm{~V}$ and the rated peak-to-peak fluctuation voltage $\Delta v_{d \max }=4.5 \mathrm{~V}$ are obtained. The errors between the theoretical and experimental values are caused by the reverse recovery current of $1.5 \mathrm{~A}$ in the practical diodes.

For the improvement of the input total power factor, the authors propose the commutation capacitor that is connected to across each diode in the diode rectifier circuit. The commutation capacitors $C_{c}=0.1 \mu \mathrm{F}$ to obtain the unity input total power factor are designed according to derived design method. Fig. 4 shows the experimental waveforms of the diode rectifier circuit with the commutation capacitors under the rated load. The ideal rectangular waveform in the input current $i_{u}$ is obtained. The input total power factor $T P F$ is improved to 0.992 .
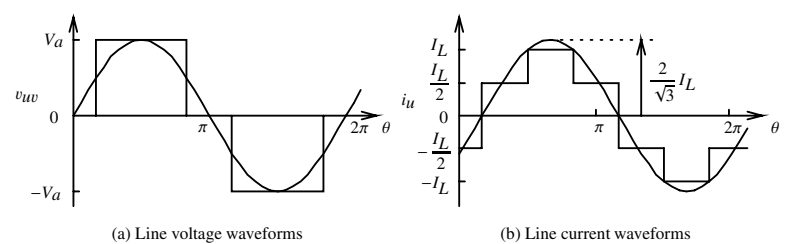

Fig. 1. Sinusoidal and rectangular waveforms

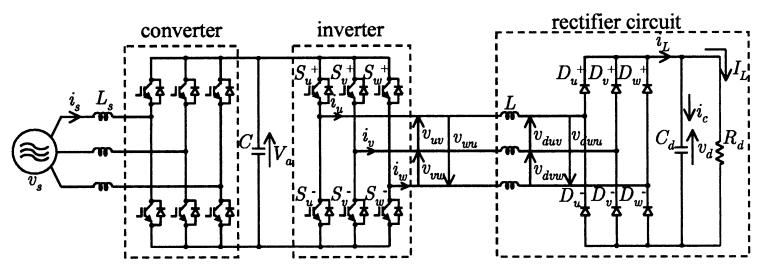

Fig. 2. Model of three-phase rectangular-waveform distribution system

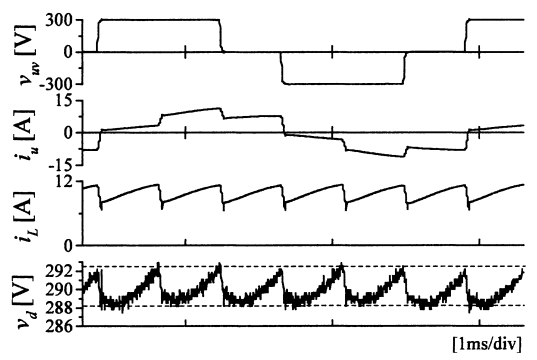

Fig. 3. Experimental waveforms of diode rectifier circuit

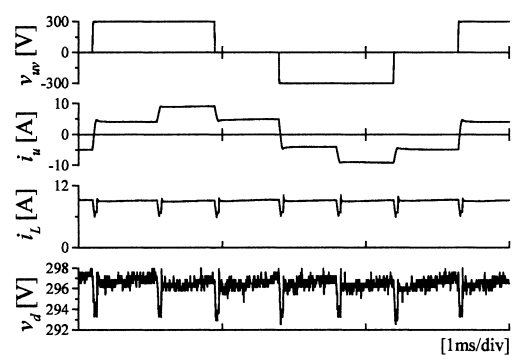

Fig. 4. Experimental waveforms of diode rectifier circuit with commutation capacitors. 


\title{
三相方形波配電システムの負荷ダイオード整流回路の特性
}

\author{
学生員 渡邊真一郎* 上級会員 竹下 隆晴* \\ 正 員 西田 保幸**
}

\section{Characteristics of Diode Rectifier Circuits for Three-Phase Rectangular-Waveform Distribution System}

Shin-ichiro Watanabe*, Student Member, Takaharu Takeshita*, Senior Member, Yasuyuki Nishida**, Member

This paper presents the characteristics of diode rectifier circuits for the three-phase rectangular-waveform distribution system. Both the amplitude and the rms value of the line current in the proposed rectangular-waveform distribution system can be reduced to $\sqrt{3} / 2$ of those in the conventional sinusoidal-waveform distribution system under the same $\mathrm{dc}$ output voltage of the rectifier circuit. From the analysis of the diode rectifier circuit in steady state, the design method of the input inductance and the output capacitance are derived. Furthermore, the commutation capacitors to improve the input total power factor of the diode rectifier circuit are proposed. In order to verify the effectiveness of the proposed methods, the experimental characteristics of the rectifier circuits are shown.

キーワード：三相方形波配電システム, ダイオード整流回路, 転流キャパシタ

Keywords: three-phase rectangular-waveform distribution system, diode rectifier circuit, commutation capacitor

\section{1. まえがき}

現在, 高圧送電系統から工場・家庭内の配電に至るまで, 一般的に正弦波交流が用いられている。これは，正弦波に より送電，変圧および事故時の遮断が容易に行えるためで ある。一方，モータドライブ，照明，空調などの多くの産 業用や家庭用機器はインバー夕を用い, また, その制御回 路もディジタル化されているため, 整流回路により交流を 直流に変換している。このため, 直流配電システムが検討 されている(1)。交流に比較し, 直流では, 遮断器などの保 護装置が高価になり，また，安全性の面においても問題が 残る。直流配電システムのこれら問題の改善法として, 方 形波配電システムが提案されている。近藤らにより単相配 電に適した方形波配電システムが提案されているが，この 方式は直接三相に適用できないとされている(2)，また，野 口らにより台形波波形による三相配電システムが提案され ているが(3), この場合，負荷に用いるダイオード整流回路 は 120 度通電で動作する。

\footnotetext{
* 名古屋工業大学 大学院工学研究科

干 466-8555 名古屋市昭和区御器所町

Graduate School of Engineering, Nagoya Institute of Technology

Gokiso, Showa, Nagoya 466-8555

** 日本大学 工学部

干 963-8642 郡山市田村町德定字中河原 1

Collage of Engineering, Nihon University

1, Naka-gawara, Tokusada, Tamura, Koriyama 963-8642
}

本論文では，180 度通電方式の方形波配電システム ${ }^{(4)}$ お よび負荷ダイオード整流回路の設計法を提案している。提 案する三相方形波配電システムは, 需要家構内にPWM コ ンバータとインバータにより構成される正弦波/方形波変換 器を設置し, 商用交流電圧をコンバータで直流に変換し, インバータにより $400 \mathrm{~Hz}$ の三相方形波交流電圧を供給す る。1 180 度通電方式であることから 120 度通電方式に比較 し, 方形波配電システムのインバータおよび負荷整流回路 の素子利用率と力率を高くできる。まず, 正弦波配電に比 較した方形波配電の利点を示す。次に, 三相方形波配電シ ステムの負荷として用いるダイオード整流回路の定常状態 の動作波形解析をし, ダイオード整流回路の入力リアクト ルと出力直流コンデンサの設計指針を示す。さらに，整流 回路の入力力率改善法として各ダイオードに微少容量のコ ンデンサを並列接続する回路を提案し, 並列コンデンサの 適正容量を明らかにしている(5)。これら提案法の有効性を 試作システムによる実験で検証する。

\section{2. 方形波配電システムとダイオード整流回路の解析}

$\langle\mathbf{2} \cdot \mathbf{1}\rangle$ 正弦波配電と方形波配電の比較 図 1 は，三 相正弦波配電システムと三相方形波配電システムで総合力 率 1 の同一電力における線間電圧波形 $v_{u v}$ と線電流波形 $i_{u}$ である。ダイオード整流により得られる直流電圧が同程度 になるように，線間電圧波高值を共に $V_{a}$ としており，整 流回路の素子耐圧は両者で等しくなる。電流波形について 
は，方形波の電流波高值を $I_{L}$ としている。表 1 は，図 1 の正弦波と方形波の電圧・電流の波高值，実効值および電 力をまとめたものである。方形波は正弦波に対し，電流波 高值および電流実効值を共に $\sqrt{3} / 2(=0.87)$ 倍にでき，又 イッチング素子の最大電流定格, 線路の電流容量を共に低 くできる。

〈2・2〉 システム構成と電圧方程式図 2 は提案する 三相方形波配電システムのモデルである。正弦波から方形 波への変換器はコンバータ・インバータシステムより構成 されている。コンバータ部は，PWM 制御により一定の直 流電圧指令值 $V_{a}^{*}$ 通りの電圧 $V_{a}$ が得られるように，入力電 流 $i_{s}$ を入力電圧 $v_{s}$ と同相の力率 1 の正弦波波形に制御す る。インバータ部は, 各相に位相差 120 度の 180 度通電パ タンを与え三相方形波交流電圧を出力する。三相ダイオー ド整流回路は, 入力にインダクタンス $L$, 出力に直流キャ パシタンス $C_{d}$ を持ち, 方形波電圧を整流し, 直流出力電 圧 $v_{d}$ を得る。

図 2 の方形波配電システムで方形波電源電圧 $v_{u v}, v_{v w}$, $v_{w u}$, インダクタンス通過後の線間電圧 $v_{d u v}, v_{d v w}, v_{d w u}$, 整 流回路入力電流 $i_{u}, i_{v}, i_{w}$ の関係は整流回路の入力インダ

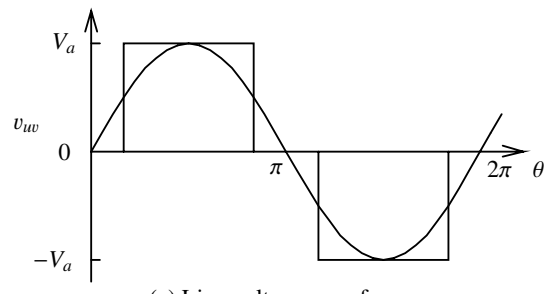

(a) Line voltage waveforms

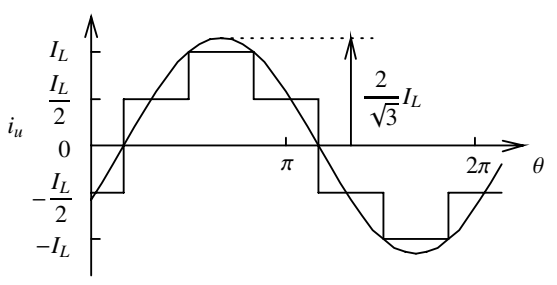

(b) Line current waveforms

図 1 正弦波・方形波波形

Fig. 1. Sinusoidal and rectangular waveforms.
クタンス $L$ を用いて次式で与えられる。

$$
\left[\begin{array}{l}
v_{u v} \\
v_{v w} \\
v_{w u}
\end{array}\right]=\left[\begin{array}{ccc}
L & -L & 0 \\
0 & L & -L \\
-L & 0 & L
\end{array}\right] \frac{d}{d t}\left[\begin{array}{l}
i_{u} \\
i_{v} \\
i_{w}
\end{array}\right]+\left[\begin{array}{l}
v_{d u v} \\
v_{d v w} \\
v_{d w u}
\end{array}\right]
$$

$i_{u}+i_{v}+i_{w}=0$

ここで, 図 2 のインバータ部のスイッチング関数 $S_{u}, S_{v}$, $S_{w}$ および負荷ダイオード整流回路のスイッチング関数 $D_{u}$, $D_{v}, D_{w}$ をそれぞれ

$$
\begin{aligned}
& S_{u}, S_{v}, S_{w}=\left\{\begin{array}{l}
1:+ \text { 側スイッチオン } \\
0: \text {-側スイッチオン }
\end{array} \quad .\right. \\
& D_{u}, D_{v}, D_{w}=\left\{\begin{array}{l}
1:+ \text { 側ダイオードオン } \\
0:- \text { 側ダイオードオン }
\end{array}\right.
\end{aligned}
$$

と定義すると，方形波電圧およびダイオード整流回路入力 電圧は次式で与えられる。

$$
\begin{aligned}
& {\left[\begin{array}{l}
v_{u v} \\
v_{v w} \\
v_{w u}
\end{array}\right]=\left[\begin{array}{l}
S_{u}-S_{v} \\
S_{v}-S_{w} \\
S_{w}-S_{u}
\end{array}\right] V_{a}} \\
& {\left[\begin{array}{l}
v_{d u v} \\
v_{d v w} \\
v_{d w u}
\end{array}\right]=\left[\begin{array}{c}
D_{u}-D_{v} \\
D_{v}-D_{w} \\
D_{w}-D_{u}
\end{array}\right] V_{d}}
\end{aligned}
$$

また，整流回路出力電流 $i_{L}$ は次式で得られる。

$$
i_{L}=D_{u} i_{u}+D_{v} i_{v}+D_{w} i_{w}
$$

$\langle\mathbf{2} \cdot \mathbf{3}\rangle$ 総合力率 1 の動作波形 図 3 は, 整流回路の入

\begin{tabular}{|c|c|c|c|c|c|}
\hline \multirow[t]{2}{*}{ waveform } & \multicolumn{2}{|c|}{ line voltage $v_{u v}$} & \multicolumn{2}{|c|}{ line current $i_{u}$} & \multirow{2}{*}{ power } \\
\hline & amplitude & RMS & amplitude & RMS & \\
\hline sinusoidal & $V_{a}$ & $\frac{1}{\sqrt{2}} V_{a}$ & $\frac{2}{\sqrt{3}} I_{L}$ & $\sqrt{\frac{2}{3}} I_{L}$ & $V_{a} I_{L}$ \\
\hline rectangular & $V_{a}$ & $\sqrt{\frac{2}{3}} V_{a}$ & $I_{L}$ & $\frac{1}{\sqrt{2}} I_{L}$ & $V_{a} I_{L}$ \\
\hline
\end{tabular}
力総合力率 1 における三相方形波配電システムの線間電圧 $v_{u v}, v_{v w}, v_{w u}$, 線電流 $i_{u}, i_{v}, i_{w}$ の波形である。線間電圧波形

表 1 正弦波と方形波の電圧電流比較

Table 1. Voltage and current between sinusoidal and rectangular waveforms.

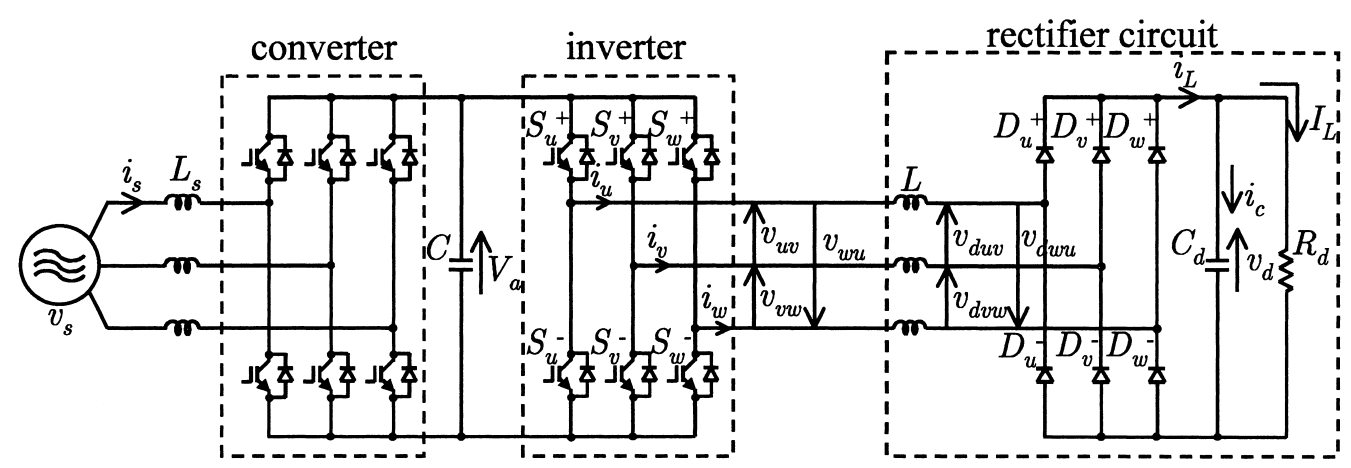

図 2 三相方形波配電システムのモデル

Fig. 2. Model of three-phase rectangular-waveform distribution system. 


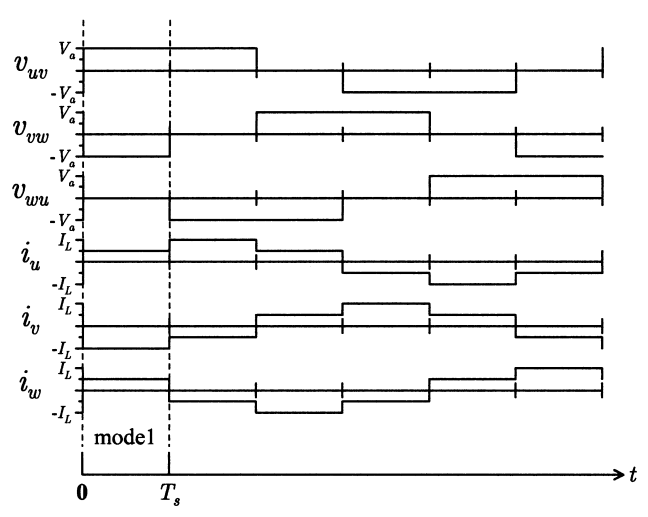

図 3 総合力率 1 の三相方形波電圧・電流波形

Fig. 3. Voltage and current waveforms of three-phase rectangular-waveform system in unity total power factor.

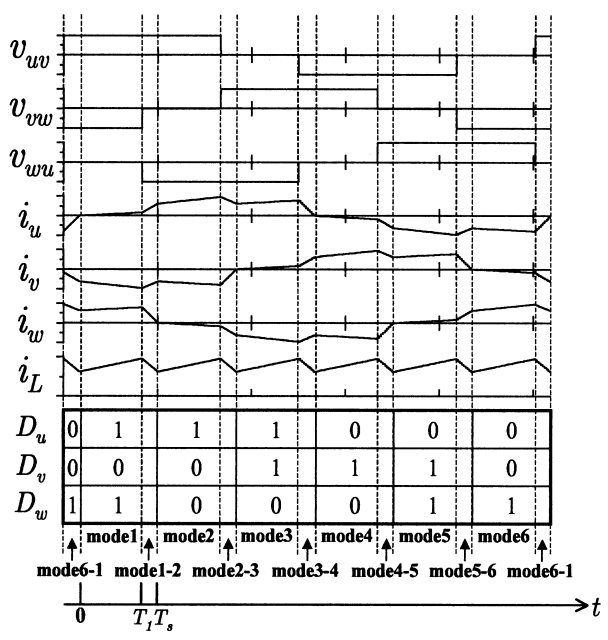

図 4 ダイオード整流回路の動作波形

Fig. 4. Operating waveforms of diode rectifier circuit.

は波高值 $V_{a}$ で, 線電流波形は負荷電流值 $I_{L}$ を波高值とする $\pm I_{L}, \pm I_{L} / 2$ の 4 レベルの階段状波形である。整流回路の動作 を図 3 のモード 1 で説明する。モード 1 のインバー夕およ びダイオードのスイッチング関数 $\left(S_{u}, S_{v}, S_{w}\right),\left(D_{u}, D_{v}, D_{w}\right)$ は共に $(1,0,1)$ であり，各線間電圧は, $v_{u v}=V_{a}, v_{v w}=-V_{a}$, $v_{w u}=0$ と得られる。 $u, w$ 相の線電流 $i_{u}=i_{w}=I_{L} / 2$ は, $D_{u}^{+}, D_{w}^{+}$をそれぞれ通って整流回路出力側で合流し, 負荷 電流 $I_{L}$ となり, $D_{v}^{-}$を通って, $i_{v}=-I_{L}$ としてインバー夕 に戻る。

〈2・4〉 ダイオード特性を考慮した動作波形 図 4 は ダイオード特性を考慮した整流回路の入力電圧，電流波形 およびダイオード整流回路の導通素子を示している。整流 回路入力電流の正負が反転する際, 電流が零になった後, 入 カインダクタンス $L$ のために線電流は零から徐々に増加ま たは減少していく。このため整流回路の入力総合力率は 1 から低下するが，依然として高力率が保たれる。

ダイオード整流回路の動作解析のために, 方形波電圧お よびダイオードの導通状態から図 4 に示すようにモード 1〜モード 6-1 をそれぞれ定義する。モード 1〜6は，イン

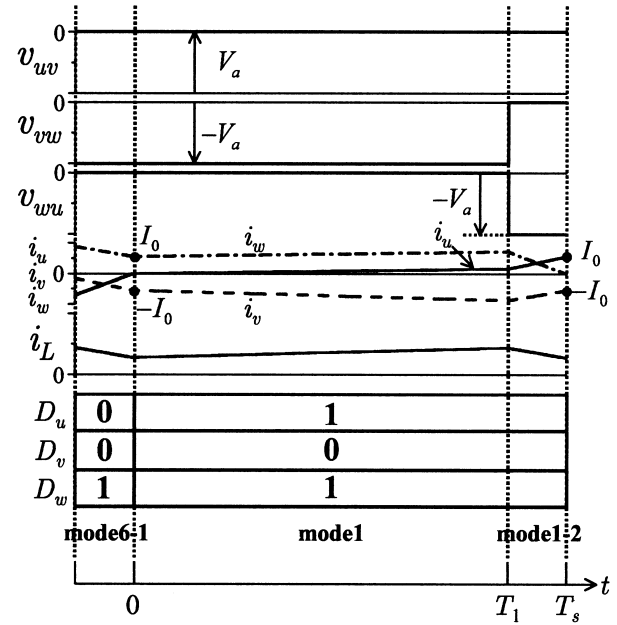

困 5 モード 6-1 からモード 1-2 の動作波形

Fig. 5. Operating waveforms between mode6-1 and mode1-2.

バータのスイッチング関数とそれに対応した整流回路のス イッチング関数の值が一致している場合である。例えば, モード 1 では, $\left(S_{u}, S_{v}, S_{w}\right),\left(D_{u}, D_{v}, D_{w}\right)$ は共に $(1,0,1)$ で ある。モード1-2〜6-1では，インバー夕は次のモードに遷 移しているが，整流回路は電流の連続性からモードが変化 していない場合である。例えば，モード1-2では，インバー 夕では $\left(S_{u}, S_{v}, S_{w}\right)$ はモード2の $(1,0,0)$ であるが, 整流回 路では $\left(D_{u}, D_{v}, D_{w}\right)$ がモード 1 の $(1,0,1)$ の状態である。

図 5 は, 図 4 のモード 6-1 からモード 1-2を拡大した波 形である。モード 1 の方形波配電システムの線間電圧は, $v_{u v}=V_{a}, v_{v w}=-V_{a}, v_{w u}=0$ である。モード 1 の開始時間 を $t=0$ として, $u, v, w$ 相の初期電流はそれぞれ $i_{u}(0)=0$, $i_{v}(0)=-I_{0}, i_{w}(0)=I_{0}$ である。 $i_{u}, i_{w}$ は, 時間 $t$ と共に増加 し， $i_{v}$ は減少する。時間 $t=T_{1}$ でインバータのスイッチを $S_{w}^{+}$から $S_{w}^{-}$へ切り替えることで，モード 1-2 に遷移する。 時間 $t=T_{s}$ で各相電流 $i_{u}\left(T_{s}\right)=I_{0}, i_{v}\left(T_{s}\right)=-I_{0}, i_{w}\left(T_{s}\right)=0$ と なり，モード1-2 は終了する。

$\langle\mathbf{2} \cdot \mathbf{5}\rangle$ 電流波形解析 整流回路の入出力電流の定常 状態解析において簡単化のために，ダイオード整流回路の 直流平滑コンデンサ容量 $C_{d}$ は十分大きいとし, 出力電圧 $v_{d}=V_{d}$ および負荷電流 $I_{L}$ は直流の一定值として解析する。

(2) 式を(1) 式へ代入して， $v_{u v}, v_{v w}$ について求めると次 式が得られる。

$$
\left[\begin{array}{l}
v_{u v} \\
v_{v w}
\end{array}\right]=\left[\begin{array}{cc}
L & -L \\
L & 2 L
\end{array}\right] \frac{d}{d t}\left[\begin{array}{l}
i_{u} \\
i_{v}
\end{array}\right]+\left[\begin{array}{l}
v_{d u v} \\
v_{d v w}
\end{array}\right]
$$

ダイオード整流回路の出力電力により直流電圧 $V_{d}$ は変 化するので, $V_{d}$ の関数として電流初期值 $I_{0}$ とモード 1 の 期間 $T_{1}$ を，図 5 のモード 1 ，モード 1-2 の期間で考える。 モード 1 では $\left(S_{u}, S_{v}, S_{w}\right),\left(D_{u}, D_{v}, D_{w}\right)$ は共に $(1,0,1)$ で あり，(5)，(6) 式を(8) 式に代入してモード 1 における電流 $i_{u}, i_{v}$ が次式で得られる。 


$$
\begin{array}{r}
{\left[\begin{array}{c}
i_{u}(t) \\
i_{v}(t)
\end{array}\right]=\frac{1}{3 L}\left[\begin{array}{cc}
1 & -1 \\
-2 & 2
\end{array}\right]\left[\begin{array}{c}
V_{a} \\
V_{d}
\end{array}\right] t+\left[\begin{array}{c}
0 \\
-I_{0}
\end{array}\right]} \\
\left(0 \leq t \leq T_{1}\right)
\end{array}
$$

モード 1-2 では, $\left(S_{u}, S_{v}, S_{w}\right)$ が $(1,0,0)$ となるので, 電流 $i_{u}, i_{v}$ が次式で得られる。

$$
\begin{aligned}
{\left[\begin{array}{l}
i_{u}(t) \\
i_{v}(t)
\end{array}\right]=} & \frac{1}{3 L}\left[\begin{array}{cc}
2 & -1 \\
-1 & 2
\end{array}\right]\left[\begin{array}{c}
V_{a} \\
V_{d}
\end{array}\right]\left(t-T_{1}\right) \\
& +\left[\begin{array}{l}
i_{u}\left(T_{1}\right) \\
i_{v}\left(T_{1}\right)
\end{array}\right] \quad\left(T_{1} \leq t \leq T_{s}\right)
\end{aligned}
$$

(9), (10) 式および $t=T_{s}$ におけるモード 1-2 の最終值 $i_{u}\left(T_{s}\right)=I_{0}, i_{v}\left(T_{s}\right)=-I_{0}$ を用いて $T_{1}, I_{0}$ を解くと次式が 得られる。

$$
\begin{aligned}
& T_{1}=\frac{\left(2 V_{d}-V_{a}\right) T_{s}}{V_{a}} \\
& I_{0}=\frac{\left(V_{a}-V_{d}\right) T_{s}}{L} \cdots
\end{aligned}
$$

負荷電流 $I_{L}$ は，整流回路出力電流 $i_{L}$ の時間平均值であ る。(7) 式を用いてモード 1 ，モード $1-2 よ り ~ I_{L}$ を計算す ると次式が得られる。

$$
I_{L}=\frac{1}{T_{s}} \int_{0}^{T_{s}}\left(i_{u}+i_{w}\right) d t=\frac{2\left(V_{a}^{2}-V_{d}^{2}\right) T_{s}}{3 L V_{a}}
$$

（13）式を変形し, 整流回路出力電圧 $V_{d}$ を次式により負荷 電流 $I_{L}$ に読みかえることができる。

$$
V_{d}=\sqrt{V_{a}^{2}-\frac{3 L V_{a} I_{L}}{2 T_{s}}} .
$$

〈2·6 負荷電力と入力総合力率 ダイオード整流回 路の負荷電力 $P_{\text {LLoad }}$ は, (13) 式を用いて次式で得られる。

$$
P_{\text {Load }}=V_{d} I_{L}=\frac{2 V_{d}\left(V_{a}^{2}-V_{d}^{2}\right) T_{s}}{3 L V_{a}} .
$$

ダイオード整流回路の入力電圧 $v_{u v}$ の実効值 $V_{u v}$, 入力電流 $i_{u}$ の実効值 $I_{u}$ は，半周期の電圧・電流波形よりそれぞれ次 式で与えられる。

$$
\begin{aligned}
V_{u v} & =\sqrt{\frac{1}{3 T_{s}} \int_{0}^{3 T_{s}} v_{u v}{ }^{2} d t}=\sqrt{\frac{2}{3}} V_{a} \ldots \ldots \\
I_{u} & =\sqrt{\frac{1}{3 T_{s}} \int_{0}^{3 T_{s}} i_{u}^{2} d t} \\
& =\frac{\left(V_{a}-V_{d}\right) \sqrt{8\left(V_{a}+V_{d}\right)^{2}-3 V_{a}^{2}} T_{s}}{3 \sqrt{3} L V_{a}}
\end{aligned}
$$

ダイオード整流回路の入力総合力率 $T P F$ は, (15) (17) 式 を用いて次式で得られる。

$$
T P F=\frac{P_{-L o a d}}{\sqrt{3} V_{u v} I_{u}}=\frac{\sqrt{6} V_{d}\left(V_{a}+V_{d}\right)}{V_{a} \sqrt{8\left(V_{a}+V_{d}\right)^{2}-3 V_{a}^{2}}}
$$

\section{3. 整流回路パラメータ設計指針}

〈3.1〉 入カリアクトル ダイオード整流回路の仕様 として, 定格状態に扔ける出力電圧 $V_{d}$, 出力電流 $I_{L}$, 入力 総合力率 TPF が与えられた場合, 入力リアクトル $L$ の設 計指針を示す。まず，(18) 式にて， $V_{d}$ と $T P F$ が設計条件 を満たすことを確認する。もし，設計条件を満たさない場 合には, $V_{d}$ と $T P F$ の設計仕様の変更が必要になる。次に, 出力電圧 $V_{d}$ が決まると, 負荷電力 $P_{\text {LLoad }}\left(=V_{d} I_{L}\right)$ が得ら れ，(15) 式から入力リアクトルのインダクタンス $L$ を次式 で設計できる。

$$
L=\frac{2 V_{d}\left(V_{a}^{2}-V_{d}^{2}\right) T_{s}}{3 P_{\text {Load }} V_{a}} .
$$

$\langle 3 \cdot 2\rangle$ 直流平滑コンデンサ 図 6 に, ダイオード整 流回路の負荷電流 $I_{L}$ が一定とした場合のコンデンサ電流 $i_{c}$ とコンデンサ電圧 $v_{d}$ の波形を示す。コンデンサ電圧 $v_{d}$ の 最大電圧変動幅 $\Delta v_{d \max }$ の仕様を与えることで直流コンデン サ $C_{d}$ の設計指針を示す。

モード 1 におけるコンデンサ電流 $i_{c}$ は，(2)，(7)，(9), (12)，(13) 式を用いて次式で得られる。

$$
\begin{gathered}
i_{c}(t)=i_{L}-I_{L}=\frac{V_{a}-V_{d}}{3 L V_{a}}\left\{2 V_{a} t-\left(2 V_{d}-V_{a}\right) T_{s}\right\} \cdots \\
\left(0 \leq t \leq T_{1}\right)
\end{gathered}
$$

モード 1 の最大電圧変動幅 $\Delta v_{d 1}$ は, $t=0 \sim T_{1} / 2$ の間の電 圧差として次式で得られる。

$$
\begin{aligned}
\Delta v_{d 1} & =-\frac{1}{C_{d}} \int_{0}^{T_{1} / 2} i_{c} d t \\
& =\frac{\left(V_{a}-V_{d}\right)\left(2 V_{d}-V_{a}\right)^{2} T_{s}^{2}}{12 C_{d} L V_{a}^{2}} .
\end{aligned}
$$

同様に，モード $1-2$ におけるコンデンサ電流 $i_{c}$ と最大電圧 変動幅 $\Delta v_{d 12}$ は次式でそれぞれ得られる。

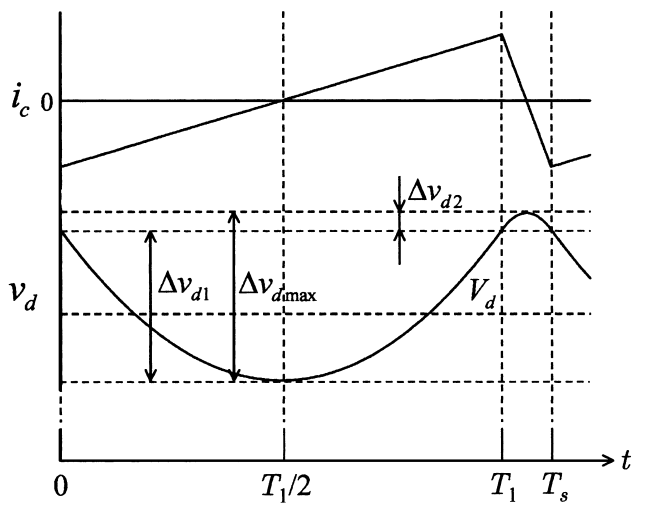

図 6 直流平滑コンデンサの電圧・電流波形 Fig. 6. Current and voltage waveforms of dc smoothing capacitor. 


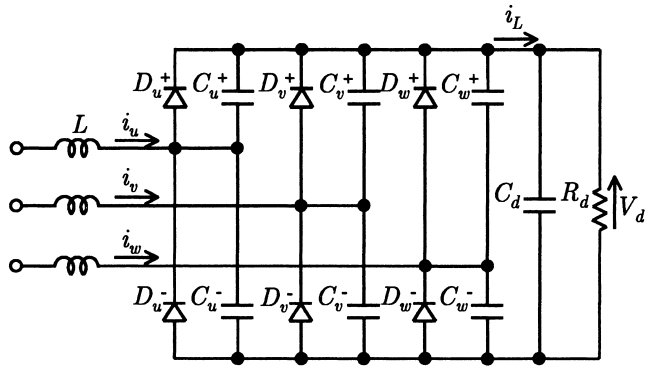

図 7 転流キャパシタ付きダイオード整流回路

Fig. 7. Diode rectifier circuit with commutation capacitors.

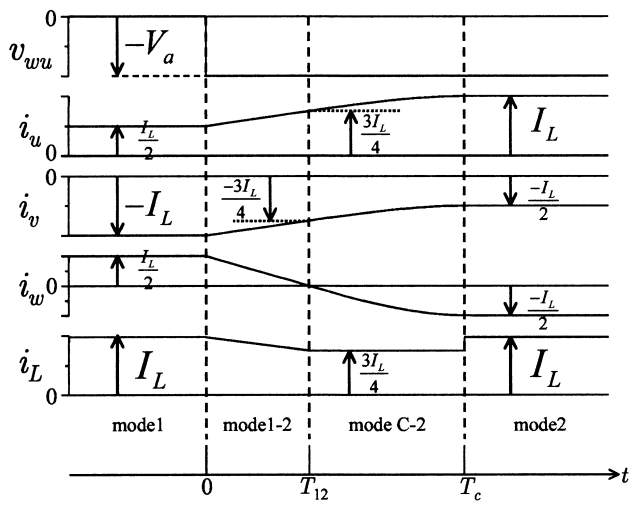

図 8 転流キャパシタ付きダイオード整流回路の 電压・電流波形

Fig. 8. Voltage and current waveforms of diode rectifier circuit with commutation capacitors.

$$
\begin{gathered}
i_{c}(t)=\frac{2 V_{d}-V_{a}}{3 L V_{a}}\left\{-V_{a}\left(t-T_{1}\right)+\left(V_{a}-V_{d}\right) T_{s}\right\} \\
\left(T_{1} \leq t \leq T_{s}\right) \\
\Delta v_{d 12}=\frac{\left(V_{a}-V_{d}\right)^{2}\left(2 V_{d}-V_{a}\right) T_{s}^{2}}{6 C_{d} L V_{a}^{2}} \ldots \ldots . .
\end{gathered}
$$

最大電圧変動幅 $\Delta v_{d \max }\left(=\Delta v_{d 1}+\Delta v_{d 12}\right)$ とするための直流 コンデンサ容量 $C_{d}$ は次式で設計できる。

$$
C_{d}=\frac{\left(V_{a}-V_{d}\right)\left(2 V_{d}-V_{a}\right) T_{s}^{2}}{12 \Delta v_{d \max } L V_{a}}
$$

\section{4. 転流キャパシタによる力率改善}

ダイオード整流回路の入力総合力率の改善を目的として, 図 7 に示すように各ダイオードに微少容量のコンデンサを 並列接続する回路構成を提案する。並列コンデンサは，電 流反転時に逆極性の電流が得られるように働き，この結果， 入力電流波形として図 3 に示す $\pm I_{L}$ から $\pm I_{L} / 2$ の 4 レべ ルの波形が得られ，入力総合力率を改善できる。この並列 コンデンサを以下では転流キャパシタと呼ぶ。

図 8 は，転流キャパシ夕接続時のモード 1 からモード 2 に至る電圧・電流波形である。転流キャパシタの動作説明 の簡単化のために, 整流回路の出力電圧 $v_{d}\left(=V_{d}\right)$ は一定值 で方形波の波高值に等しく， $V_{d}=V_{a}$ と近似する。 モード 1: $\left(S_{u}, S_{v}, S_{w}\right),\left(D_{u}, D_{v}, D_{w}\right)$ は共に $(1,0,1)$ で,

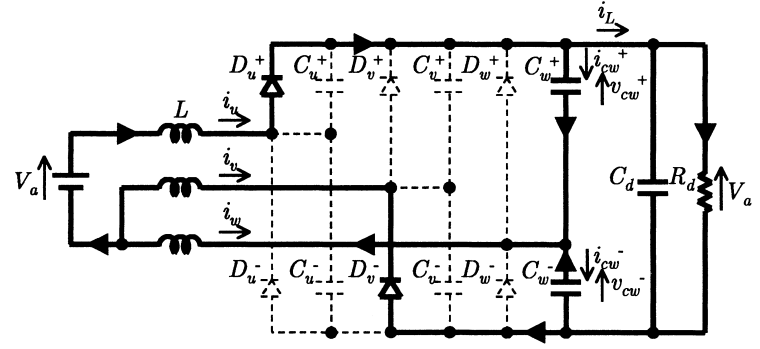

困 9 モード C-2 の回路接続状態

Fig. 9. Circuit in mode C-2.

$V_{d}=V_{a}$ のため, 入力電流は $i_{u}=I_{L} / 2, i_{v}=-I_{L}, i_{w}=I_{L} / 2$ と 一定值とする。

モード 1-2: 時間原点 $t=0$ をモード 1-2 の開始時点とする。 $t=0$ で $\left(S_{u}, S_{v}, S_{w}\right)$ が $(1,0,0)$ に変化し，(10) 式を用いて, 入力電流 $i_{u}, i_{v}, i_{w}$ は次式で得られる。

$$
\begin{array}{r}
{\left[\begin{array}{c}
i_{u}(t) \\
i_{v}(t) \\
i_{w}(t)
\end{array}\right]=\frac{V_{a}}{3 L}\left[\begin{array}{c}
1 \\
1 \\
-2
\end{array}\right] t+\left[\begin{array}{c}
I_{L} / 2 \\
-I_{L} \\
I_{L} / 2
\end{array}\right]} \\
\left(0 \leq t \leq T_{12}\right)
\end{array}
$$

時間 $t=T_{12}$ で, 入力電流 $i_{u}, i_{v}, i_{w}$ は,

$$
\left[\begin{array}{c}
i_{u}\left(T_{12}\right) \\
i_{v}\left(T_{12}\right) \\
i_{w}\left(T_{12}\right)
\end{array}\right]=\left[\begin{array}{c}
3 I_{L} / 4 \\
-3 I_{L} / 4 \\
0
\end{array}\right]
$$

となり, ダイオード $D_{w}^{+}$がオフし，モード $1-2$ が終了する。 このとき，モード 1-2 の期間 $T_{12}$ は次式で与えられる。

$$
T_{12}=\frac{3 L I_{L}}{4 V_{a}}
$$

モード C-2: 転流キャパシタにより新たに発生したモード であり，回路の接続状態を図 9 に示す。 $w$ 相の両ダイオー ドはオフし,$w$ 相の正側転流キャパシタ $C_{w}{ }^{+}$の電圧は零か ら $V_{a}$ まで充電され, 負側転流キャパシタ $C_{w}{ }^{-}$の電圧は $V_{a}$ から零まで放電されるので, $w$ 相ダイオードは転流キャパ シタにより零電圧スイッチングとなる。転流キャパシタの 容量 $C_{c}$ を用いて, (1) 式の電圧方程式, 転流キャパシタ電 圧 $v_{c w}^{+}, v_{c w}^{-}$, 転流キャパシタ電流 $i_{c w}^{+}, i_{c w}^{-}$に関し, 以下の式 が成立する。

$$
\begin{aligned}
& {\left[\begin{array}{c}
V_{a} \\
0 \\
-V_{a}
\end{array}\right]=\left[\begin{array}{ccc}
L & -L & 0 \\
0 & L & -L \\
-L & 0 & L
\end{array}\right] \frac{d}{d t}\left[\begin{array}{c}
i_{u} \\
i_{v} \\
i_{w}
\end{array}\right]+\left[\begin{array}{c}
V_{a} \\
-v_{c w}^{-} \\
-v_{c w}^{+}
\end{array}\right] \ldots \ldots \ldots \ldots \ldots \ldots \ldots \ldots \ldots \ldots \ldots \ldots \ldots \ldots \ldots \ldots \ldots \ldots \ldots \ldots \ldots} \\
& {\left[\begin{array}{c}
v_{c w}^{+} \\
v_{c w}^{-}
\end{array}\right]=\frac{1}{C_{c}} \int\left[\begin{array}{c}
i_{c w}^{+} \\
i_{c w}^{-}
\end{array}\right] d t \ldots \ldots \ldots \ldots \ldots \ldots \ldots \ldots}
\end{aligned}
$$

また， $w$ 相転流キャパシタの初期電流，電圧は次式で与え られる。

$$
\left[\begin{array}{c}
i_{c w}^{+}\left(T_{12}\right) \\
i_{c w}^{-}\left(T_{12}\right)
\end{array}\right]=\left[\begin{array}{l}
0 \\
0
\end{array}\right], \quad\left[\begin{array}{c}
v_{c w}^{+}\left(T_{12}\right) \\
v_{c w}^{-}\left(T_{12}\right)
\end{array}\right]=\left[\begin{array}{c}
0 \\
V_{a}
\end{array}\right] .
$$

(2)，(28)〜(30) 式を，(26)，(31) 式の初期值を用いて，整 


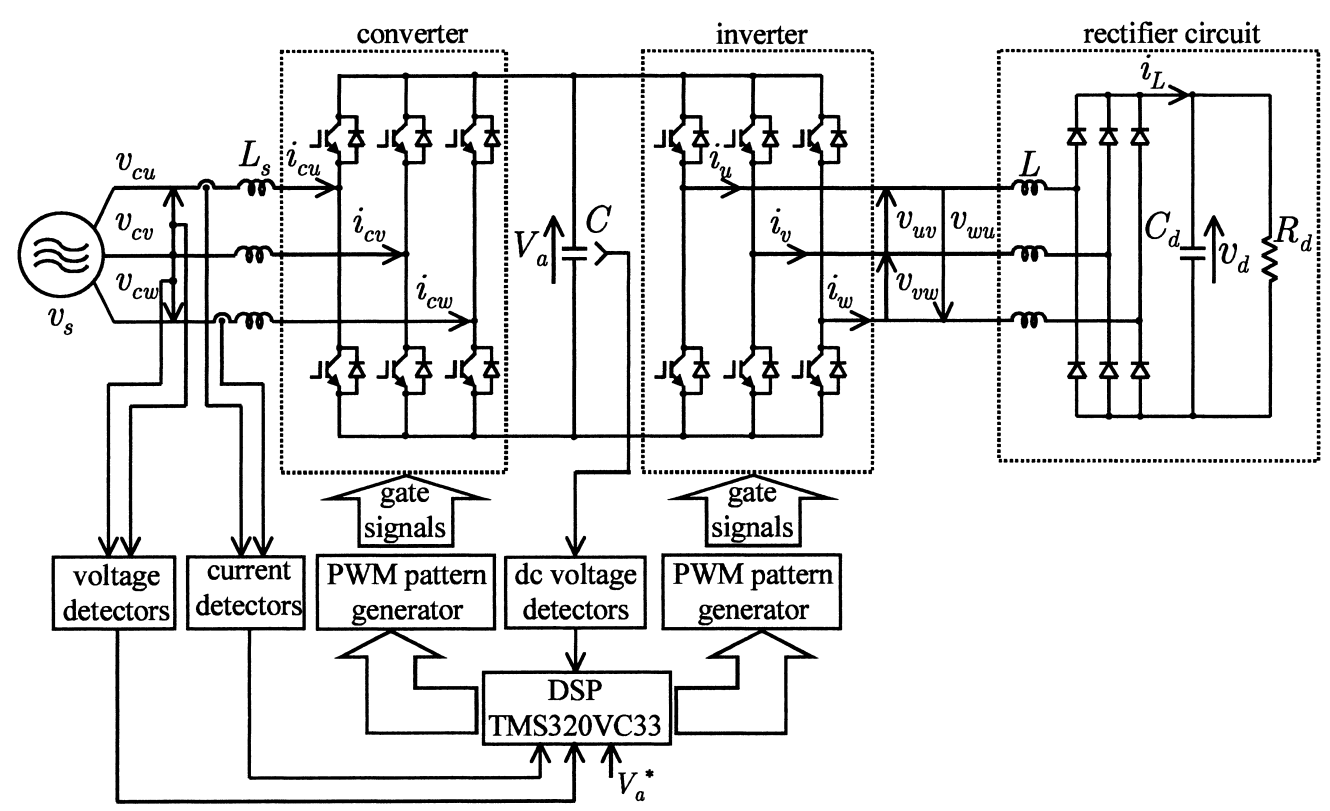

困 10 試作システムの構成

Fig. 10. Experimental system configration.

流回路入力電流と転流キャパシ夕電圧，電流を解くと次式 が得られる。

$$
\begin{gathered}
{\left[\begin{array}{c}
i_{u} \\
i_{v} \\
i_{w}
\end{array}\right]=V_{a} \sqrt{\frac{C_{c}}{3 L}} \sin \frac{t-T_{12}}{\sqrt{3 L C_{c}}}\left[\begin{array}{c}
1 \\
1 \\
-2
\end{array}\right]+\frac{3 I_{L}}{4}\left[\begin{array}{c}
1 \\
-1 \\
0
\end{array}\right]} \\
\ldots \ldots \ldots \ldots \ldots \\
{\left[\begin{array}{c}
i_{c w}{ }^{+} \\
i_{c w}{ }^{-}
\end{array}\right]=V_{a} \sqrt{\frac{C_{c}}{3 L}} \sin \frac{t-T_{12}}{\sqrt{3 L C_{c}}}\left[\begin{array}{c}
1 \\
-1
\end{array}\right] \ldots \ldots \ldots \ldots} \\
{\left[\begin{array}{c}
v_{c w}{ }^{+} \\
v_{c w}{ }^{-}
\end{array}\right]=V_{a} \cos \frac{t-T_{12}}{\sqrt{3 L C_{c}}}\left[\begin{array}{c}
-1 \\
1
\end{array}\right]+V_{a}\left[\begin{array}{l}
1 \\
0
\end{array}\right] \ldots \ldots \ldots} \\
\left(T_{12} \leq t \leq T_{c}\right)
\end{gathered}
$$

図 8 に示すようにモードC-2 の終了時，すなわち，時間 $t=T_{c}$ で, 転流キャパシタ電圧 $v_{c w}^{+}=V_{a}, v_{c w}^{-}=0$, 整流回路 入力電流 $i_{u}=I_{L}, i_{v}=i_{w}=-I_{L} / 2$ と設計するには, 転流キャ パシタ $C_{c}$ を次式で与えればよい。

$$
C_{c}=\frac{3 L I_{L}^{2}}{16 V_{a}^{2}}
$$

このとき，モード C-2 の期間 $T_{c 2}$ は，次式で得られる。

$$
T_{c 2}=T_{c}-T_{12}=\frac{\pi \sqrt{3 L C_{c}}}{2}=\frac{3 \pi L I_{L}}{8 V_{a}}
$$

モード 2: $w$ 相負側ダイオード $D_{w}{ }^{-}$がオンし, $\left(S_{u}, S_{v}, S_{w}\right)$, $\left(D_{u}, D_{v}, D_{w}\right)$ は共に $(1,0,0)$ で, $V_{d}=V_{a}$ であり，入力電流 $i_{u}=I_{L}, i_{v}=i_{w}=-I_{L} / 2$ は一定值を保つ。

\section{5. 実験結果}

〈5・1〉 システム構成 図 10 に実験に用いた試作シス
表 2 試作システムの仕様と回路定数

Table 2. Specifications and circuit constants of experimental system.

\begin{tabular}{l|c}
\hline Converter-inverter system & $200 \mathrm{~V}$ \\
source voltage $v_{s}$ & $60 \mathrm{~Hz}$ \\
source frequency $f_{s}$ & $300 \mathrm{~V}$ \\
dc voltage $V_{a}$ & $300 \mathrm{~V}$ \\
amplitude of output voltage $V_{a}$ & $400 \mathrm{~Hz}$ \\
frequency of output voltage $f_{a}$ & $417 \mu \mathrm{s}$ \\
sixth period of output voltage $T_{s}$ & $4.0 \mathrm{mH}$ \\
input inductance $L_{s}$ & $1880 \mu \mathrm{F}$ \\
dc capacitance $C$ & $20 \mathrm{kHz}$ \\
switching frequency $f_{c}$ & \\
Diode rectifier circuit & $3.0 \mathrm{~kW}$ \\
rated output power $P_{-}$Load & $290 \mathrm{~V}$ \\
rated output voltage $V_{d}$ & $10.3 \mathrm{~A}$ \\
rated output current $I_{L}$ & $2.5 \mathrm{~V}$ \\
rated output voltage ripple $\Delta v_{d m a x}$ & 0.88 \\
rated input total power factor $T P F$ & $0.5 \mathrm{mH}$ \\
input inductance $L$ & $100 \mu \mathrm{F}$ \\
dc capacitance $C_{d}$ & $0.1 \mu \mathrm{F}$ \\
comutation capacitance $C_{c}$ &
\end{tabular}

テム構成を, 表 2 に回路定数をそれぞれ示す。電源電圧 $v_{s}$ には線間電圧 $200 \mathrm{~V}$, 周波数 $60 \mathrm{~Hz}$ の平衡三相正弦波電圧 を用いている。方形波変換器であるコンバータ・インバー タシステムの制御回路は, DSP (TI 社製 TMS320VC33)を 中心に構成されており, 制御周期 $50 \mu \mathrm{s}$ である。コンバー 夕回路では，スイッチング周波数 $20 \mathrm{kHz}$ の PWM 制御に より, 入力総合力率 1 と直流電圧 $V_{a}=300 \mathrm{~V}$ 一定值の制御 をしている。インバータ回路では, 出力周波数 $400 \mathrm{~Hz}$, 波 高值 $V_{a}=300 \mathrm{~V}$ の方形波電圧を出力している。

ダイオード整流回路は, 定格出力 $P_{\text {LLoad }}=3 \mathrm{~kW}$, 定格電 圧 $V_{d}=290 \mathrm{~V}$, 定格出力電流 $I_{L}=10.3 \mathrm{~A}$ とし, ダイオード 


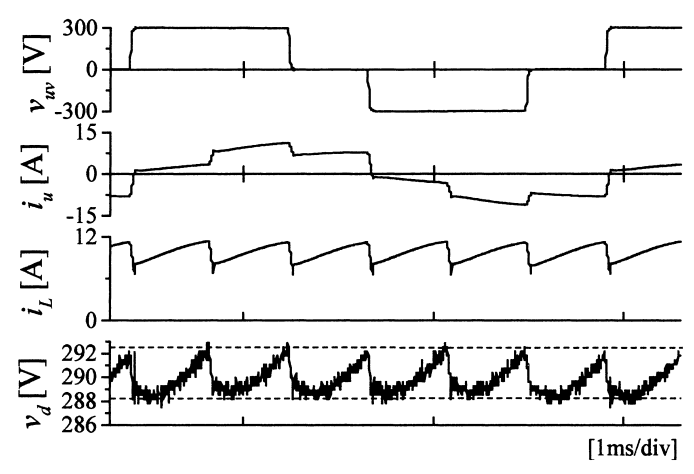

図 11 ダイオード整流回路の実験波形

Fig. 11. Experimental waveforms of diode rectifier circuit.

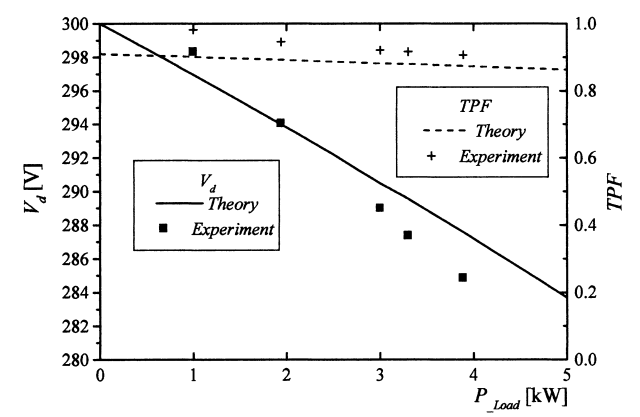

図 12 ダイオード整流回路の出力電圧と入力総 合力率の特性

Fig. 12. Characteristics of output voltage and input total power factor of diode rectifier circuit.

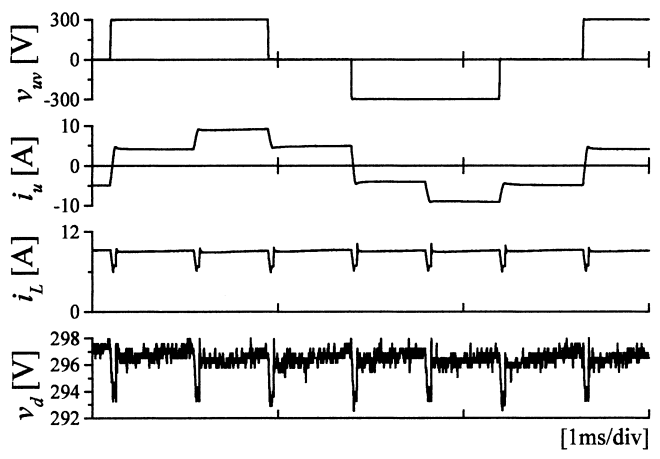

図 13 転流キャパシタ付きダイオード整流回路 の実験波形

Fig. 13. Experimental waveforms of diode rectifier circuit with commutation capacitors.

は東芝社製 50J6P41 を使用している。入力リアクトルは, (19) 式より $L=0.5 \mathrm{mH}$ としている。このとき，(18) 式より 入力総合力率 $T P F=0.88$ と得られる。直流平滑コンデン サは，(24) 式より定格時のリプル電圧 $\Delta v_{d \max }=2.5 \mathrm{~V}$ とし て, $C_{d}=100 \mu \mathrm{F}$ としている。

$\langle\mathbf{5} \cdot \mathbf{2}\rangle$ ダイオード整流回路の実験結果図 11 は, ダ イオード整流回路の定格負荷状態における方形波配電シス テム出力電圧 $v_{u v}$, 整流回路入力電流 $i_{u}$, 出力電流 $i_{L}$, 出力 電圧 $v_{d}$ の実験波形を示している。理論値と同様の実験波形
が得られているが，理論值では考虑していないダイオード の逆回復電流 $1.5 \mathrm{~A}$ による誤差が発生している。具体的に は，方形波電圧波形 $v_{u v}$ の立ち上がり時に，理想ダイオー ドでは入力電流 $i_{u}$ が零になった時点でモード 1 に遷移する が，ダイオードの逆回復電流により $1.5 \mathrm{~A}$ まで立ち上がっ た時点でモード 1 に遷移し，その後，緩やかに入力電流 $i_{u}$ が上昇している。この電流波形により, 入力総合力率 $T P F$ は，理論值 0.88 に対して実験值では 0.92 に改善されてい る。整流回路出力電流 $i_{L}$ は, ダイオードの転流時に逆回復 電流分だけ低くなり，このとき，直流電圧 $v_{d}$ が $2 \mathrm{~V}$ ほど低 下するので, 最大電圧変動幅 $\Delta v_{d \text { max }}$ は理論值 $2.5 \mathrm{~V}$ に対し て実験值では $4.5 \mathrm{~V}$ と大きくなっている。出力電圧は，ほ ほ理論值通りで $V_{d}=289 \mathrm{~V}$ が得られている。

図 12 は出力電力 $P_{\text {LLoad }}$ に対する整流回路出力電圧 $V_{d}$ と 入力総合力率 $T P F$ の特性である。出力電圧 $V_{d}$ の理論值は, (14), (15) 式から得られ, 理論值と実験值の最大誤差は $2 \mathrm{~V}$ であり, 両者はよく一致している。出力電圧 $V_{d}$ は, 出力電 力 $P_{-}$Load の増加と共に低下するが, 低下量は方形波電圧波 高值 $V_{a}=300 \mathrm{~V}$ の $5 \%$ 程度であり，ほほ一定の出力電圧が 得られている。入力総合力率 $T P F$ の理論值は, (14), (18) 式から得られている。実験值の $T P F$ は 0.90 以上になって おり, 理論值に比較して高いのは, 既に述べたように, ダ イオードの逆回復電流によるものである。

〈5・3〉 転流キャパシタ付き整流回路の実験結果 ダイ オード整流回路の入力総合力率を改善するための転流キャ パシタは, (35) 式により $C_{c}=0.11 \mu \mathrm{F}$ と計算されるが, 実 験では $C_{c}=0.1 \mu \mathrm{F}$ を用いている。図 13 は, 転流キャパシ 夕を用いたときの方形波配電システムの出力電圧 $v_{u v}$, 線路 電流 $i_{u}$, 整流回路出力電流 $i_{L}$, 整流回路出力電圧 $v_{d}$ の実験 波形である。転流キャパシタの働きにより，入力電流波形 $i_{u}$ は階段波になり, 入力総合力率 $T P F=0.992$ に改善され ている。図 8 に示したように, 整流回路出力電流 $i_{L}$ はダイ オード転流時に $3 I_{L} / 4$ まで低下するため, 出力電圧 $v_{d}$ は転 流時に $4 \mathrm{~V}$ ほど低下するが，ほほ一定の直流電圧が得られ ている。

\section{6. あとがき}

本論文では，三相方形波配電システムに扔けるダイオー ド整流回路の定常状態の理論解析と実験特性を明らかにし ている。まず，従来の正弦波配電と提案する方形波配電に 抒いて整流後の直流電圧が等しい条件の下で, 方形波波形 は正弦波波形に比較して, 電流波高值㧍よび電流実効值を 共に $\sqrt{3} / 2$ 倍に低減でき, スイッチング素子の最大電流定 格, 線路の電流容量を共に低くできることを明らかにして いる。ダイオード整流回路の定常状態解析から, 負荷電力 に対する出力直流電圧と入力総合力率の関係式を導出し, これらをもとに入力リアクトルと出力直流コンデンサの設 計指針を示している。さらに，入力総合力率を改善するた めの転流キャパシ夕を提案し, 転流キャパシ夕容量の設計 指針を明らかにしている。 
$3 \mathrm{~kW}$ 試作システムによる実験で, ダイオード整流回路の 出力電力に対して直流出力電圧は $5 \%$ 以内の電圧降下であ り, また, 入力総合力率は 0.90 以上の特性が得られている。 また，転流キャパシタの導入により，定格時に入力総合力 率を 0.992 に改善できている。

今後，負荷急变時の整流回路の過渡特性を明らかにする 予定である。

(平成 18 年 3 月 15 日受付, 平成 18 年 10 月 10 日再受付)

\section{文献}

(1) R. Zhang, F.C. Lee, D. Boroyevich, C. Liu, and L. Chen: "AC Load Conditioner and DC Bus Conditioner for a DC Distribution Power System", Proceedings of the 2000 IEEE 31st Annual Power Electronics Specialists Conference, Vol.1, pp.107-112 (2000)

(2) S. Kondo and H. Meguro: "Feasibility Study on Square-wave-voltage power Distribution System", IEEJ Trans., Vol.116-D, No.5, pp.556-562 (1996-5) (in Japanese)

近藤正示・目黒 光:「方形波配電システムの可能性の検討」, 電学 論 D, 116, 5, pp.556-562 (1996-5)

(3) Y. Sato and T. Noguchi: "Trapezoidal-Wave-Voltage Power Distribution System with UPS Function", Proceedings of the 1999 Japan Industy Applications Society Conference, Vol.1, pp.219-222 (1999) (in Japanese) 佐藤祥和・野口季彦：「無停電電源機能を有する台形波配電システ 厶」, 平 11 電学産業応用部門大会, Vol.1, pp.219-222 (1999)

(4) W. Sugiyama, S. Watanabe, and T. Takeshita: "Configuration and Performance of Three-Phase Rectangular-Wave Distribution System", The Papers of Joint Technical Meeting on Semiconductor Power Converter and Industry Electric and Electronic Application, IEE Japan, SPC-04-102/IEA-04-29, pp.55-60 (2004-6) (in Japanese)

杉山 渉・渡邊真一郎・竹下隆晴 :「三相方形波配電システムの構 成と特性」, 電気学会半導体電力变換/産業電力電気応用合同研資, SPC-04-102/IEA-04-29, (2004-6)

(5) S. Watanabe, T. Takeshita, and Y. Nishida: "Design of Rectifier Circuit for Three-Phase Rectangular-Wave Distribution System", The Papers of Joint Technical Meeting on Semiconductor Power Converter and Linear Drivers, IEE Japan, SPC-05-117/LD-05-74 (2005-12) (in Japanese) 渡邊真一郎・竹下隆晴・西田保幸:「三相方形波配電用ダイオード 整流回路の設計法」, 電気学会半導体電力変換リニアドライブ合同研 資, SPC-05-117/LD-05-74 (2005-12)
渡 邊 真一郎 (学生員) 1981 年 4 月 27 日生。 2003 年 3 月大

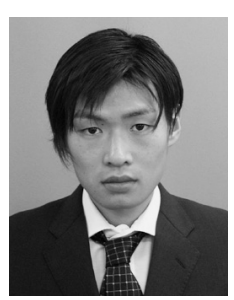
阪工業大学電気電子システム工学科卒業。2006 年 3 月名古屋工業大学大学院博士前期期課程情報工 学専攻修了。同年 4 月三菱電機 (株) 入社, 現在 に至る。在学中, 主として, 配電システムに関す る研究に従事。

竹 下 隆 晴 (上級会員) 1959 年 8 月 23 日生。 1984 年 3 月

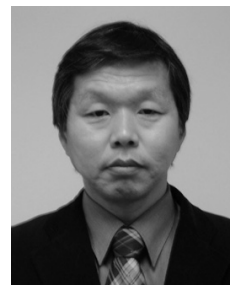
名古屋工業大学大学院修士課程修了。同年 4 月岐 阜工業高等専門学校助手。1991 年 4 月名古屋工 業大学電気情報工学科講師。助教授を経て, 2003 年 1 月教授, 現在に至る。工学博士。パワーエレ クトロニクスの教育と研究に従事。2002 年電気 学会学術振興賞 (論文賞) 受賞。計測自動制御学 会，高速信号処理応用技術学会，IEEE 各会員。

西田保 幸 (正員) 1956 年 10 月 19 日生。1984 年 3 月東京

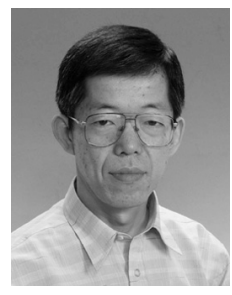
電機大学大学院修士課程修了。1998 年 3 月山口大 学大学院博士後期課程修了 (博士 (工学))。同年 4 月日本大学工学部電気電子工学科勤務, 講師を 経て, 2000 年助教授, 現在に至る。パワーエレク トロニクスに関する教育, 教育ツール開発, 研究 に従事。IEEE 会員, パワーエレクトロニクス学会 会員，EPE 会員，PCIM Advisory Board Member。 スイス連邦工科大学客員研究員（2007 年 4 月～9 月） 